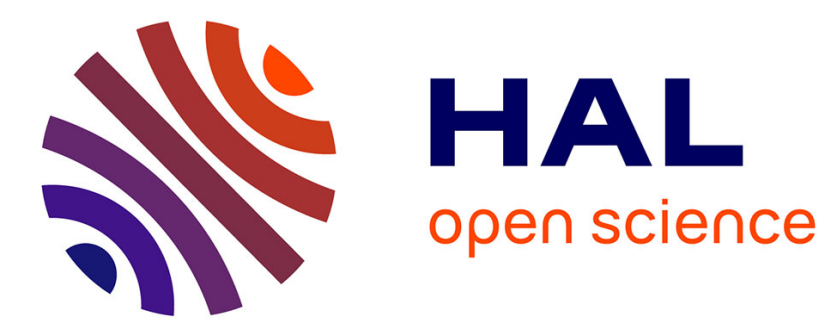

\title{
Influenza risk at Muslim pilgrimages in Iraq and Saudi Arabia \\ Philippe Gautret
}

\section{To cite this version:}

Philippe Gautret. Influenza risk at Muslim pilgrimages in Iraq and Saudi Arabia. Travel Medicine and Infectious Disease, 2018, 21, pp.1-2. 10.1016/j.tmaid.2017.10.016 . hal-01780716

\section{HAL Id: hal-01780716 \\ https://hal.science/hal-01780716}

Submitted on 11 Apr 2019

HAL is a multi-disciplinary open access archive for the deposit and dissemination of scientific research documents, whether they are published or not. The documents may come from teaching and research institutions in France or abroad, or from public or private research centers.
L'archive ouverte pluridisciplinaire HAL, est destinée au dépôt et à la diffusion de documents scientifiques de niveau recherche, publiés ou non, émanant des établissements d'enseignement et de recherche français ou étrangers, des laboratoires publics ou privés. 


\title{
Influenza risk at Muslim pilgrimages in Iraq and Saudi Arabia
}

\author{
A R T I C L E I N F O
}

\author{
Keywords: \\ Arbaeen \\ Hajj \\ Umrah \\ Influenza
}

The study by Yavarian et al. [1] is a major contribution to the field of mass gathering medicine for two reasons. Firstly, this is one among the very few studies addressing respiratory diseases in Karbala pilgrims in Iraq and in Umrah pilgrims to Mecca, Saudi Arabia. Secondly, the design of the study includes a control group selected from the general population of Iran to which pilgrims can be compared. A Shiite Muslim pilgrimage takes place each year in Karbala, an Iraqi city of approximately 500,000 inhabitants located $100 \mathrm{~km}$ south-east of the capital, Baghdad. The "Ashura" celebrates the death of Hussein ibn Ali, the grandson of the Prophet Mohammad at the Battle of Karbala on the $10^{\text {th }}$ day of the first month of the lunar Islamic calendar. It is followed by a 40 day-period of mourning. The "Arbaeen" celebrates the end of this 40-day period, gathering millions of pilgrims from inside and outside Iraq. In one study conducted during the celebration day of Ashura in 2010, a 7-fold increase in febrile illnesses was observed compared to baseline activity in emergency units [2]. In another study conducted in Iranian pilgrims participating to the Karbala pilgrimage and referred to Iranian clinics in Iraq in 2013, the main reason for referral was acute upper respiratory tract infection symptoms accounting for $48 \%$ of the reasons for admission [3]. In a 2016 study conducted in Arbaeen pilgrims participating to a religious $80 \mathrm{~km}$ march from Najaf to Karbala, the authors found that $25 \%$ of them were tobacco smokers, making them at risk for respiratory infections [4]. In the present paper, Yavarian and colleagues [1] evidenced by PCR a 14\% prevalence of influenza virus carriage in the throat among the 1588 Iranian pilgrims suffering from SARI on returning from Karbala where they celebrated the 2013 to 2015 Arbaeen. This prevalence was of 12\% in 2067 pilgrims returning from Mecca and of $9 \%$ in 38,511 Iranian citizens from the overall population suffering from SARI and sampled from 2013 to 2015 . The odds ratio for influenza infection in ill Karbala pilgrims and ill Mecca pilgrims compared to ill Iranians that did not participate to a pilgrimage was respectively of 1.65 $(1.42-1.91, \mathrm{p}<0.0001)$ and $1.40(1.22-1.60, \mathrm{p}<0.0001)$. Altogether these results confirm that participation to religious mass gatherings in Saudi Arabia or Iraq exposes Iranian pilgrims to a high risk of acute respiratory infections and that part of these infections are likely due to the influenza virus [5]. Vaccination against influenza is therefore highly advisable in pilgrims participating to religious mass gatherings in the Middle East including the Hajj and Umrah [5] and other pilgrimages like those in Karbala. When comparing Umrah and Hajj pilgrims in the Iranian study, it appeared that the proportion of ill pilgrims with influenza was of 4\% in Hajj pilgrims and 27.0\% in Umrah pilgrims from 2013 to 2015 [OR $=6.19$ (4.56-8.41), p < 0.0001]. Such a high rate of influenza infections in Umrah pilgrims compared to Hajj pilgrims had never been reported so far. Studies in Umrah pilgrims are scant. One Indian study including Umrah and Hajj pilgrims was conducted in 2014 with an overall $11 \%$ of influenza infection in pilgrims suffering from fever and/or respiratory symptoms, but comparison between Umrah and Hajj pilgrims was not provided [6]. The Umrah pilgrimage can be conducted all over the year, while the Hajj rituals officially start on the $8^{\text {th }}$ day of the $12^{\text {th }}$ month of the lunar Islamic calendar, which may possibly have consequences on the viral epidemiology of respiratory infections at the Umrah, as evidenced in the Lavarian study [1]. The Umrah is set to become a mass gathering of major importance and consequence for Saudi Arabia and internationally and clearly, more studies should be conducted specifically in Umrah pilgrims [7].

\section{References}

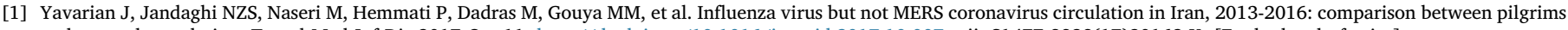
and general population. Travel Med Inf Dis 2017 Oct 11. http://dx.doi.org/10.1016/j.tmaid.2017.10.007. pii: S1477-8939(17)30162-X. [Epub ahead of print].

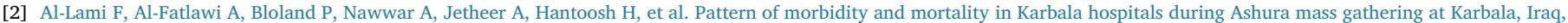
2010. East Mediterr Health J 2013;19(Suppl 2):S13-8.

[3] Mousavi J, Jafari F. Prevalence of diseases in pilgrims referring to Iranian clinics in Iraq. Int J Travel Med Glob Health 2016;4(1):31-3.

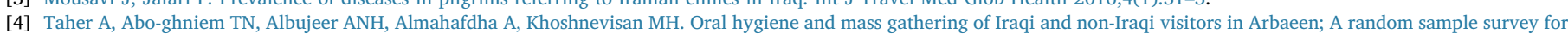
3500 visitors. Res Rev J Dent Sci 2017;5(1):92-5.

[5] Gautret P, Benkouiten S, Al-Tawfiq JA, Memish ZA. Hajj-associated viral respiratory infections: a systematic review. Travel Med Infect Dis 2016 Mar-Apr;14(2):92-109. 


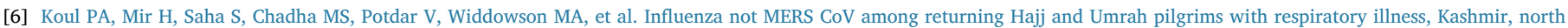
India, 2014-15. Travel Med Infect Dis 2017 Jan - Feb;15:45-7.

[7] Yezli S, Yassin Y, Awam A, Attar A, Al-Jahdali E, Alotaibi B. Umrah. An opportunity for mass gatherings health research. Saudi Med J 2017 Aug;38(8):868-71.

Philippe Gautret Unité de recherche sur les maladies infectieuses et tropicales émergentes (URMITE) CNRS-IRD UMR 6236, Méditerranée Infection, Faculté de Médecine et de Pharmacie, Aix-Marseille-Université, Marseille, France E-mail address: philippe.gautret@club-internet.fr 